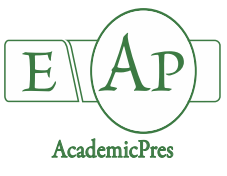

Holonec R et al. (2021)

Notulae Botanicae Horti Agrobotanici Cluj-Napoca

Volume 49, Issue 3, Article number 12401

DOI:10.15835/nbha49312401

Research Article

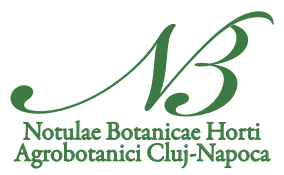

\title{
Non-chemical treatments to improve the seeds germination and plantlets growth of sessile oak
}

\author{
Rodica HOLONEC ${ }^{1}$, Oana VIMAN ${ }^{2 *}$, Irina M. MORAR ${ }^{2}$, \\ Steluța SÎNGEORZAN² ${ }^{2}$ Camelia SCHEAU ${ }^{2}$, Horia D. VLASIN ${ }^{2}$, \\ Petru TRUTA ${ }^{2}$, Horea CRIVEANU², Liviu HOLONEC ${ }^{2}$, \\ Alina M. TRUTA ${ }^{2 *}$ \\ ${ }^{I}$ Technical University of Cluj-Napoca, Department of Electrotechnics and Measurements, Cluj-Napoca, \\ Romania; rodica.holonec@ethm.utcluj.ro \\ ${ }^{2}$ University of Agricultural Sciences and Veterinary Medicine, Department of Forestry, 3-5 Mănăștur St., 400372, Cluj-Napoca, \\ Romania; wiman7777@yahoo.com (*corresponding author);irinatodea@yahoo.com; steluta_singeorzan@yahoo.com; \\ camelia.scheau22@gmail.com; horiavd@yahoo.com; truta_ptr@yahoo.com; criveanuhoria@yahoo.ro; Iholonec@yahoo.com; \\ alina_vilcan@yahoo.com (*corresponding author)
}

\begin{abstract}
The current study aimed to investigate the effect of different treatments applied to sessile oak seeds in order to improve the germination features, development and growth of seedlings. The seeds were subjected to electric field, electromagnetic field and $\gamma$ rays' treatments. For the electric field study three distinct voltages $(10 \mathrm{~V}, 30 \mathrm{~V}$ and $50 \mathrm{~V})$ and three values of exposure time $(15 \mathrm{~min} ., 35 \mathrm{~min}$. and $60 \mathrm{~min}$.) were considered. Displaying the seeds in an electric field for 60 minutes increased the germination rate with $58.89 \%$. The highest value for the seedling's height was obtained when seeds were exposed for 15 minutes at an intensity of 30V. The interaction between the intensity and the timing showed that treating seeds with $30 \mathrm{~V}$ for 35 minutes improved significantly the seedlings peculiarities. In regard to the electromagnetic field, the seeds were subjected to a single value of electromagnetic field $(B=0,4 \mathrm{mT} ; \mathrm{i}=0,680 \mathrm{~A})$ and three values of exposure time: $10 \mathrm{~min} ., 20 \mathrm{~min}$. and $30 \mathrm{~min}$. The sessile oak seeds subjected to the electromagnetic field for 20 minutes induced the highest value of germination percentage $(90.00 \%)$ and germination index $(1.81)$ and those seeds produced plantlets with high diameter $(2.69 \mathrm{~mm})$ and with significant differences towards non-treated plants. For $\gamma$ rays treatments a dosage of 2 Gy induced the highest value of germination percentage (86.67\%), of germination index (2.02); of germination energy (7.7); and of germination speed (7.24). A dosage of 6 Gy decreased the values of the same parameters. Our results showed that a dosage of 2 Gy improved also the growth parameters such as plantlets diameter $(2.65 \mathrm{~mm})$ and height $(11.25 \mathrm{~cm})$. In short, the physical treatments represent an ecological substitute approach towards the chemical substances presently used to improve seeds germination. Using physical treatments for seeds germination and growth of seedlings might be a harmless alternative for environment.
\end{abstract}

Keywords: electric field; electromagnetic field; $\gamma$ rays' treatments; seed germination; seedlings

Received: 17 Jun 2021. Received in revised form: 13 Aug 2021. Accepted: 15 Sep 2021. Published online: 23 Sep 2021.

From Volume 49, Issue 1, 2021, Notulae Botanicae Horti Agrobotanici Cluj-Napoca journal uses article numbers in place of the traditional method of continuous pagination through the volume. The journal will continue to appear quarterly, as before, with four annual numbers. 


\section{Introduction}

Quercus petraea (Matt.) Liebl., commonly known as sessile oak is taxonomically framed in Quercus genus, Fagaceae family along with other 500 species (Oldfield and Eastwood, 2007; Aldrich and CavenderBares, 2011) defining a systematic group with a great biological richness in forest ecosystems (Manos et al., 1999; Reyes and Casal, 2006).

The sessile oak is a species of tree native to Central and Western Europe, spread from Scandinavia to the Iberian Peninsula (Doody and O’Reilly, 2008; Pukacka et al., 2011). The sessile oak is the national tree of Ireland (Alan, 1974) and it is located mainly in hilly regions. In Romania the sessile oak occupies around 670.000 ha, being the most spread species of oaks, representing more than half $(56 \%)$ of the total amount of oak species (Nicolescu, 2010). Quercus petraea is a deciduous tree of great height, upon $40 \mathrm{~m}$ tall, with acorn fruits of 1.5-2.5 cm length, arranged in a sessile cup or very shortly pedunculated, acorn which matures in about 6 months (Rushforth, 1999). From ecological point of view, sessile oak is less demanding upon summer heath and more drought-tolerant, that allows it to raise more in altitude than other tree species (Mijnsbrugge et al., 2016). Quercus petraea is drought tolerant and prefers to grow in more Atlantic climates on light and welldrained, often rocky, soils (hence the specific Latin name petraea $=$ of rocky places), generally occurring on slopes and hill tops, and preferring a more acid soil pH (Eaton et al., 2016; Aas, 2000). Sessile oaks start producing acorns from the age of 40-60 years (Pukacka et al., 2011), fruiting is irregular and occurs in 4-6-year intervals (Suszka et al., 1996; Giertych and Suszka, 2011). Most deciduous tree seeds have "orthodox" characteristics which means that seeds can be dried to a moisture content of $<10 \%$ for long-term storage (Özbingol and O’Reilly, 2005). However, sessile oak seeds are recalcitrant, which means that they do not tolerate moisture loss without adversely affecting viability (Gosling, 1989; Poulsen and Eriksen, 1992; Bonner, 1996; Xia et al., 2012), making it difficult to store them for a useful period of time (Suszka and Tylkowski, 1980; Muller, 1990; Gordon, 1992b). The acorns of some species are best stored at mild freezing temperatures around -2 or $-3{ }^{\circ} \mathrm{C}$ (Suszka et al., 1996), whereas others are best stored at normal refrigerator temperatures around $2-4{ }^{\circ} \mathrm{C}$ (Connor and Bonner, 2001; Connor and Sowa, 2002, 2003). The sessile oak acorns appear to be well stored over the full range of these temperatures, from $-2{ }^{\circ} \mathrm{C}$ to $4{ }^{\circ} \mathrm{C}$ (Gordon, 1992b).

Gamma irradiation ( $\gamma$ rays) is one of the most frequent practices of genetic variation induction at many species of plants (De Micco et al., 2011; Moussa, 2006) including trees (Iglesias-Andreu et al., 2012) and morphological parts of plants. It has a considerable influence on growth and development of plantlets through genetical, cytological, biochemical, physiological inductions (Kiong et al., 2008) and morphogenetical modifications in cells and tissues closely related to irradiation levels (Ikram et al., 2010). The material and the necessary energy for initial growth are already available in seed, but some stimulants are necessary in order to activate these substances already deposited in cotyledons. The small dosages of $\gamma$ rays can activate the enzymes, and the young embryo, stimulating in the same time the cellular division and thus affect not only germination but also vegetative growth (Sjödin, 1962; Piri et al., 2011). The biological effect of $\gamma$ rays is due principally to formation of free radicals through water hydrolysis, that can lead to modulation of an anti-oxidation system, accumulation of phenolic compounds and chlorophyl pigments (Wi et al., 2006; Ashraf, 2009).

Studies regarding $\gamma$ rays were performed in order to achieve a delay in fruits maturation (World Organisation of Health and Nutrition in Agriculture, Organisation of United Nations, 1988) or to reduce bacterial populations, mushrooms, insects and other germinative pathogen agents (Gruner et al., 1992) or to optimize seeds storability. Low doses of $\gamma$ rays treatments in the seeds stimulate germination and increase fruit number and total production up to $86 \%$ (Wiendl et al., 1995).

Despite the utility of $\gamma$ rays to improve the germinative potential there are not many references in literature regarding the benefits of gamma radiation on tree species (Iglesias-Andreu et al., 2012). Most studies on seeds germination in forestry species were performed with classic methods, using physical/chemical preseeding treatments. Low doses of $\gamma$ rays treatments were used mainly to generate variation in aims of reproduction through mutation. It is well known that plants' response to $\gamma$ rays treatments is depending on 
many factors as: irradiation dosage, species or plant genotype, or which morphological part of plant is analysed (Esnault et al., 2010; De Micco et al., 2011).

Regarding the lack of references on $\gamma$ rays treatments in the seeds, the present study aimed to assess the effects of low gamma irradiation dosage on seeds' germination and growth of sessile oak plantlets.

In addition, another aim of the current study was to achieve the positive effects of the electromagnetic field (EMF) on germination and growth of plantlets. An electromagnetic field (EMF) is a natural environmental factor which has an influence to all the plants (Maffei, 2014). Numerous studies showed that along evolution process, the EMF of Earth was a natural component of the environment for living organisms (Belyavskaya et al., 2004). The phototropism and the gravitropism have been intensely studied, but there is a lack of researches regarding the impact of EMF on germination and plant growth and development. Different studies indicate positive effects of treating seeds with an EMF in some cereals and vegetable species such as bean (Huang and Wang, 2008), onion (Alexander and Doijode, 1995), tomato (De Souza et al., 2006), chickpea (Grewal and Maheshwari, 2011) and pea (Es'kov and Rodionov, 2010). Based on these studies, different species respond differently to the EMF. There is a lack of researches on the impact of EMF on sessile oak seeds, their germination and the growth of plants.

Another physical factor which may be used in the process of seed preparation and seed germination is the electric field (EF). The EF and the EMF are both non-chemical und harmless physical factors with less damaging effects on the environment (Molamofrad et al., 2013).

Several studies reported positive effects of high voltage on the yield and yield components of potatoes (Smigel et al., 1968), of cotton cultivars (Mustafayev, 1974), or of rice (Rotcharoen et al., 2002). Lynikiene et al. (2006) reported that the EF not only increased the rate of germination but also increased the germination percentage of carrot, garden radish, beet, and barely. Vasilevski (2003) showed that the use of EF and EMF in agriculture has lot of the advantages such as low toxicity and pollution of surface and underground waters which means the decrease of costs of agricultural products. This article aimed to analyse the positive effects of electric, electromagnetic field and $\gamma$ rays treatments on seeds' germination and growth of sessile oak plantlets in an experimental design.

\section{Materials and Methods}

\section{The biological material}

The sessile oak acorns were harvested manually, with the help of harvesting bags, during October 2019 from seeds' reservation Transylvania, Romania. After harvesting, seeds were deposited in well ventilated rooms (inside temperature $20^{\circ} \mathrm{C}$ ) for two months. Before sowing, seeds were immersed in water for 24 hours. The seeds that arose on surface of water were removed, being considered not viable, and those from the bottom of the pot were subsequently sorted for sowing (flotation process). A visual sorting of acorns was performed using the exterior condition as criterion, and only the seeds without visible damage were kept for study. When the relative humidity content of acorns reached the $40-50 \%$ value, the seeds were subjected to three treatments: EF, EMF and $\gamma$ rays treatments. In order to test the germination capacity, the seeds were sown in pots type Hiko, using as edaphic substrate peat $(70 \%)+$ humus $(15 \%)+$ perlite (15\%). Four repetitions each of 50 seeds were used and arranged in a completely randomized design.

\section{The effect of electric field (EF) on seed germination and seedlings}

The effect of EF on seed germination and seedlings was designed in the Biophysical Laboratory of the University of Agricultural Sciences and Veterinary Medicine, Cluj-Napoca, Romania.

The EF generator consisted of two fittings, with an adjustable distance between them, powered by a variable voltage source, between which the seed lots were placed. The EF intensity was adapted by the distance between the armature and by the voltage. The distance between the condenser armatures was $7.3 \mathrm{~cm}$ and the 
armature diameter was $26 \mathrm{~cm}$ (Figure 1). Three voltage values: $10 \mathrm{~V}, 30 \mathrm{~V}$ and $50 \mathrm{~V}$ and three distinct values of exposure timing: $15 \mathrm{~min} ., 35 \mathrm{~min}$. respectively $60 \mathrm{~min}$, were considered in this study and also a control variant.

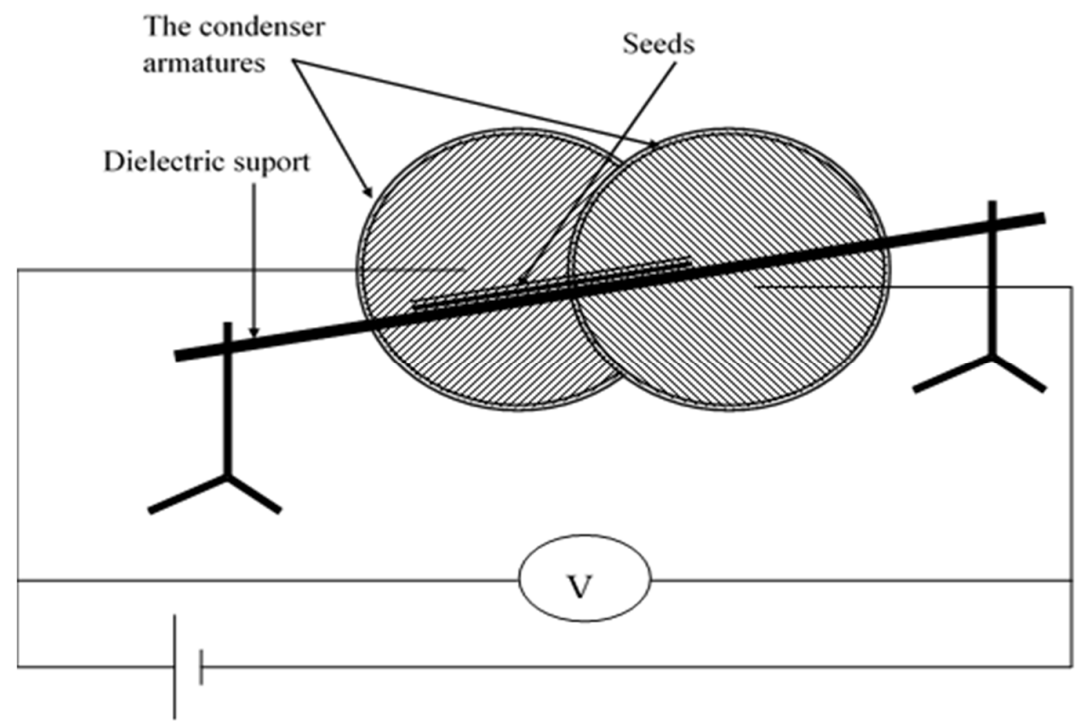

Figure 1. The diagram of seeds exposure in the electric field

\section{The effect of electromagnetic field (EMF) on seed germination and seedlings}

The effect of EMF on seed germination and seedlings was considered for a single value of EMF $B=0.4 \mathrm{mT}$ and $\mathrm{i}=0.680 \mathrm{~A}$ ( $\mathrm{B}$ - electromagnetic field, 1 Tesla $(\mathrm{T})=1000 \mathrm{millit}(\mathrm{mT})$ and $\mathrm{i}$ - electromagnetic field intensity) and three values of exposure time: $10 \mathrm{~min} ., 20 \mathrm{~min}$. and $30 \mathrm{~min}$. The EMF was performed in a Helmholtz system, where the electromagnetic induction is constant inside the coil. By modifying the supply current, is obtained the modification of the internal electromagnetic current. The seeds were exposed inside the coil, according to Figure 2.

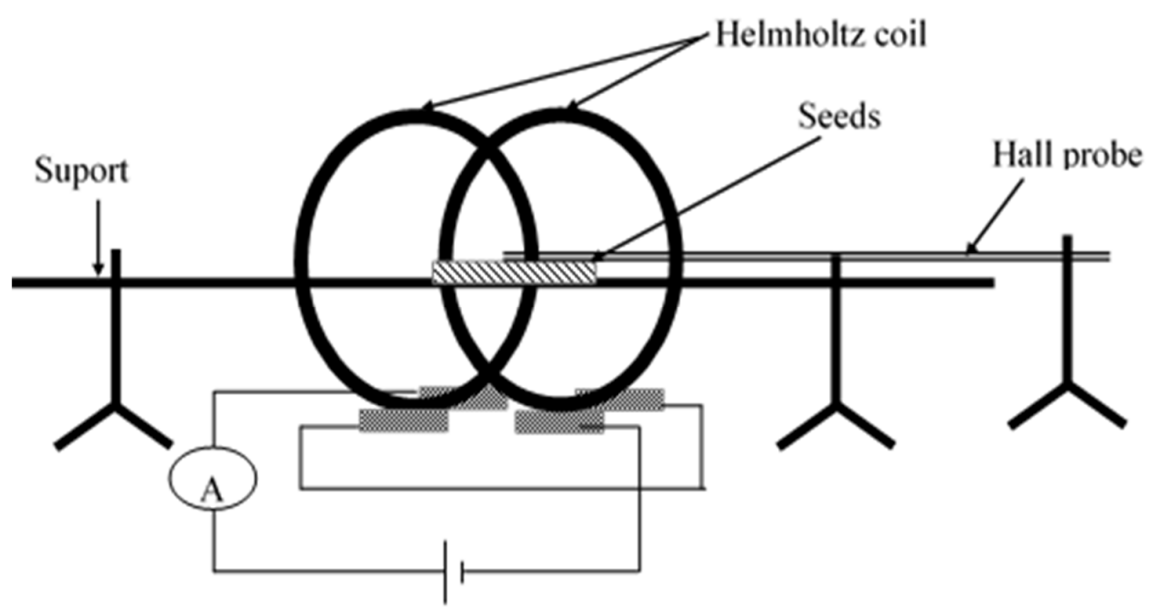

Figure 2. The diagram of seeds exposure in the electromagnetic field 


\section{The effect of $\gamma$ rays treatments on seed germination and seedlings}

The irradiation treatments of the biological material were designed within Atomic and Nuclear Physics Department of Babeş-Bolyai University, Cluj-Napoca. For this study, a Gamma Chamber 900 type device was used, using as source isotope $60 \mathrm{C}$. This device contains a ringly source, with an activity of 900 Currie.

Based of literature reports, the following treatments were considered: 1Gy-31 min, 1.5 Gy-46 min, 2 Gy-62 min. and 6 Gy-186 minutes and a control variant.

\section{The studied seeds and seedlings parameters}

The following seeds' parameters were considered in the present study: the length $(\mathrm{cm})$, the diameter $(\mathrm{cm})$ and the mass of the seeds $(\mathrm{g})$. The length and the diameter of acorns were measured with a calliper. The diameter of acorn was determined as average of two made measurements. The mass of acorn was determined with the help of analytical balance. As for growth features of plantlets, height and diameter were also considered.

\section{The studied germination parameters}

For the EMF and $\gamma$ rays treatments, seeds germination was analysed with help of the following indexes:

- GP (Germination percentage - \%) where,

- $\quad G P=\frac{\text { Number of seeds germinated per day }}{\text { Total number of seeds placed to germination }} \times 100$ (Fetouh and Hassan, 2014).

- Global method GI (Germination index) where,

- $\quad G I=\frac{\text { Number of germinated seeds }}{\text { Days from the first control }}+\cdots+\frac{\text { Number of germinated seeds }}{\text { Days from the last control }}$ (AOSA, 1983).

- SE (Germination speed/Germinative energy) where,

- $S E=\frac{\text { Number of germinated seeds in the first day of germination }}{\text { Number of germinated seeds in the last day of germination }} \times 100$ (Islam et al., 2003).

- CRG (Coefficient of germination speed) where,

- $\quad C R G=\frac{n_{1}+n_{2}+\cdots+n_{n}}{n_{1} \times T_{1}+n_{2} \times T_{2}+n_{3} \times T_{3}+\cdots+n_{n} \times T_{n}} \times 100$

- $\quad n_{1}=$ number of seeds germinated in day 1 (T1)

- $\quad n_{2}=$ number of seeds germinated in day 2 (T2)

- $\quad n_{n}=$ number of seeds germinated in day $\mathrm{n}(\mathrm{Tn})$ (Bewley and Black, 1985; Chiapusio et al., 1997).

\section{Data analysis}

To evaluate the differences between the obtained data of sessile oak seeds Boxplot was used. Two - way ANOVA was considered for the treatment of electric field, with intensity $(\mathrm{I})$ and timing $(\mathrm{T})$ as main factors, as well as interaction between these.

ANOVA single factor was considered for data regarding the height and the diameter of seeds both for electromagnetic field study and gamma ray study. If statistically significant values between averages were registered, the significance test of Tukey was applied $(\alpha=0.05)$.

\section{Results and Discussion}

\section{Results regarding seeds' characteristics}

The seeds' parameters for the mass, diameter and length were represented as a boxplot diagram (Figure 3). The minimum seeds' length recorded was $2 \mathrm{~mm}$, the maximum was $4.3 \mathrm{~mm}$, and the average $2.7 \mathrm{~mm}$. The seed diameter ranged between $1.3 \mathrm{~mm}$ and $2.9 \mathrm{~mm}$, and the seeds weighed $6.1 \mathrm{~g}$ (Figure 3).

According to the literature, a higher germination is identified in larger seeds because they contain a greater number of resources that support the germination (Kheloufi et al., 2018) and subsequently healthier seedlings (Pedrol et al., 2018). 


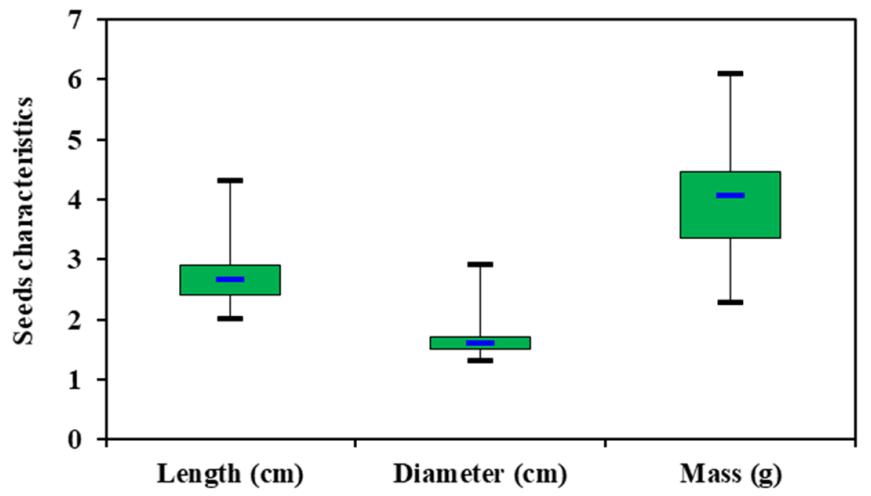

Figure 3. The chart diagram for the length, the diameter and the mass of sessile oak seeds

\section{Seed germination and plantlets growth after exposing seeds in $E F$}

The answer of sessile oak seeds exposed to three distinct voltages of EF $(10 \mathrm{~V}, 30 \mathrm{~V}, 50 \mathrm{~V})$ and three values of exposure time (15 min., $35 \mathrm{~min} ., 60 \mathrm{~min}$.) was represented as germination capacity and some important parameters of plantlets (diameter and height).

The best germination rate was registered in the case of intensity I3 $=50 \mathrm{~V}$ with $56.67 \%$, upon intensity $\mathrm{I} 2=30 \mathrm{~V}$ with $47.78 \%$ and intensity I1 $=10 \mathrm{~V}$ with $46.67 \%$. Displaying the seeds in an EF for 60 minutes increases, the germination rate with $58.89 \%$, meanwhile timing sequences of 15 minutes, or 45 minutes enhance the germination rate only with $45.56 \%$ and $46.67 \%$ respectively. The interaction between these two factors showed that I3 with $50 \mathrm{~V}$ and timing T3 with 60 minutes registered significantly superior differences (Figure 4).

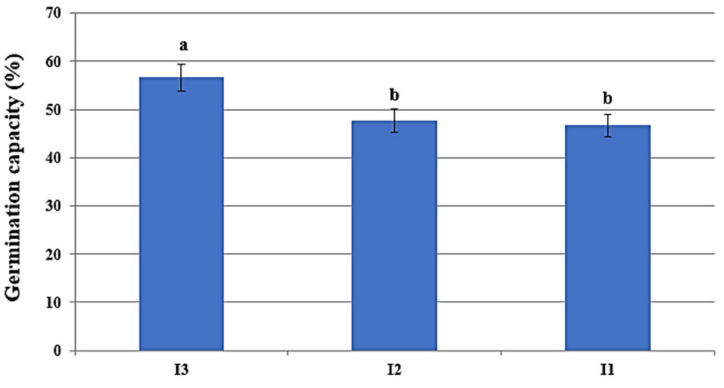

a)

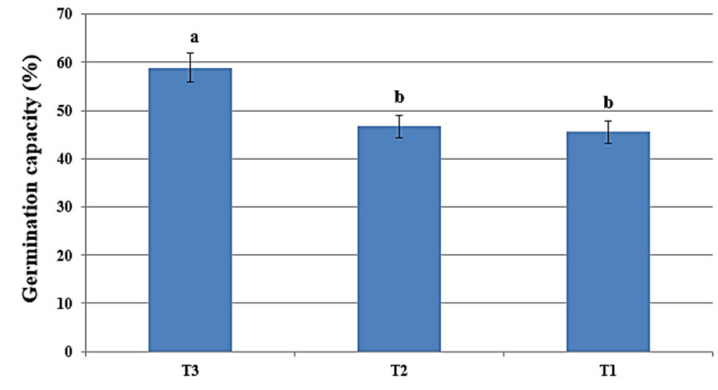

b)

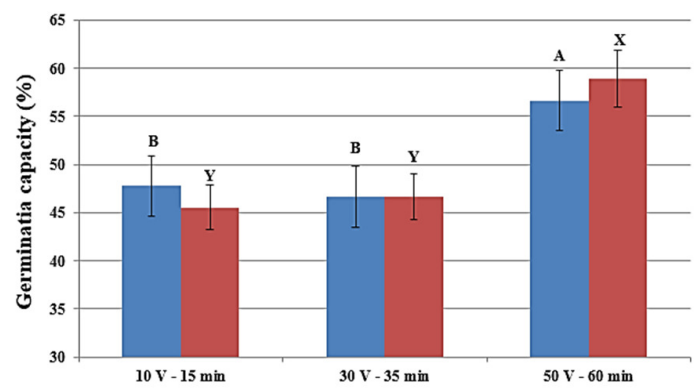

c)

Figure 4. The effects of electric field intensity (a) and timing intervals (b) as well as the interaction between these factors (c) on seeds germination of sessile oak

The bars represent the average $\pm S E(n=30)$. For each factor, different letters from top of bars indicate significant differences between treatments, according to Tukey's test $(\alpha=0.05) . \mathrm{I} 3=50 \mathrm{~V}, \mathrm{I} 2=30 \mathrm{~V}, \mathrm{I} 1=10 \mathrm{~V}$; T1 $=15 \mathrm{~min}, \mathrm{~T} 2$ $=35 \mathrm{~min}, \mathrm{~T} 3=60 \mathrm{~min}$. 
Regarding the two studied factors, EF intensity and time interval of seeds' exposure, our results highlighted that the diameter of plantlets was significantly different for $50 \mathrm{~V}$ and timing 15 min respectively. The intensity of $50 \mathrm{~V}$, registered significant differences towards the two other values $(10 \mathrm{~V}, 30 \mathrm{~V})$ for plantlets' diameter (Figure 5 a). Exposure timing of 15 minutes registered significantly inferior differences towards the two other applied timing intervals, respectively $\mathrm{T} 2=35$ minutes and $\mathrm{T} 3=60$ minutes (Figure $5 \mathrm{~b}$ ).

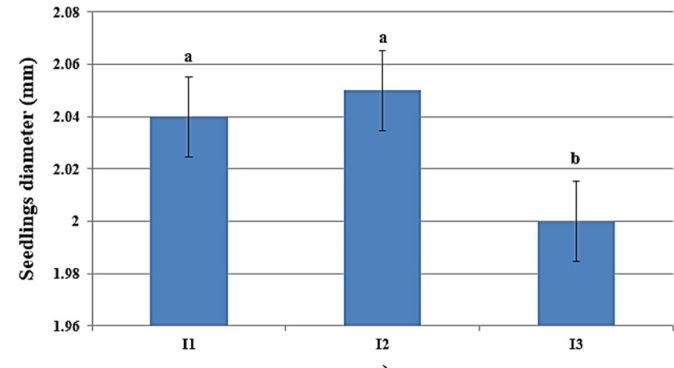

a)

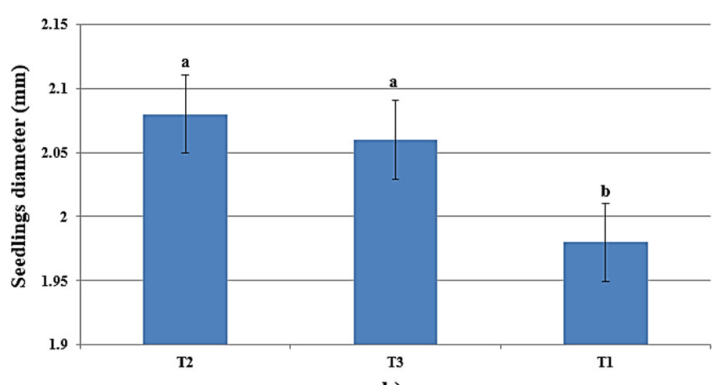

b)

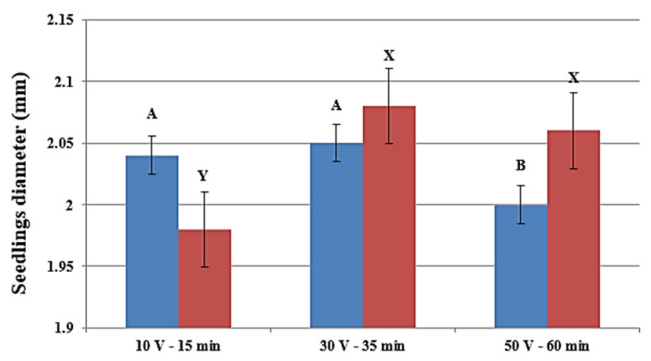

c)

Figure 5. The effects of electric field intensity (a) and timing intervals (b) as well as the interaction between these factors (c) on diameter of sessile oak seedlings

The bars represent the average $\pm S E(n=30)$. For each factor, different letters from top of the bars indicate significant differences between treatments, according Tukey's test $(\alpha=0.05)$. I3 $=50 \mathrm{~V}, \mathrm{I} 2=30 \mathrm{~V}, \mathrm{I} 1=10 \mathrm{~V} ; \mathrm{T} 1=15 \mathrm{~min}, \mathrm{~T} 2=$ $35 \mathrm{~min}, \mathrm{~T} 3=60 \mathrm{~min}$.

The highest value for the plantlet's height was obtained when seeds were exposed for 15 minutes at an intensity of EF of $30 \mathrm{~V}$ registering significant superior differences upon the other values (Figure $6 \mathrm{a}, \mathrm{b}$ ). Regarding the interaction between the analysed factors may be noted that the interaction between I2 (30V) and T2 (35 minutes) registered significantly differences upon the two other interactions, respectively I1 (10V) with T1 (15 minutes) and I3 (50V) with T3 (60 minutes) (Figure $6 \mathrm{c}$ ).

The use of EF and EMF in agriculture has had various advantages, such as low toxicity and pollution of surface and groundwater (Vasilevski, 2003). Various studies reported positive effects of high voltage on the yield and yield components of potatoes (Smigel et al., 1968). Similarly, it has been reported for certain varieties of cotton (Mustafayev, 1974) and rice (Rotcharoen et al., 2002).

Lynikeine et al. (2006) reported that the EF not only increased the germination rate, but also increased the germination rate of carrot, garden radish, beet and barely. In our study, we noticed that displaying the seeds in an $\mathrm{EF}$ for 60 minutes increase the germination rate with 58.89\%, meanwhile timing sequences of 15 minutes, or 45 minutes enhance the germination rate with $45.56 \%$ and $46.67 \%$ respectively. 


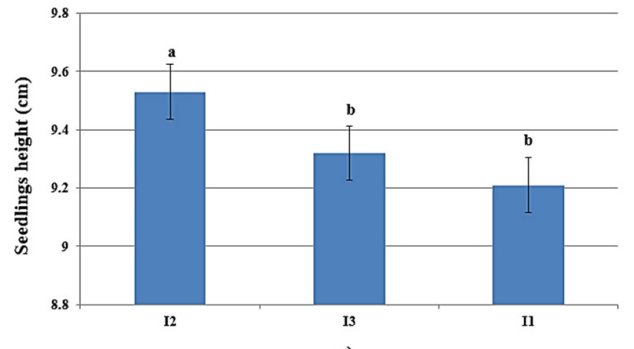

a)

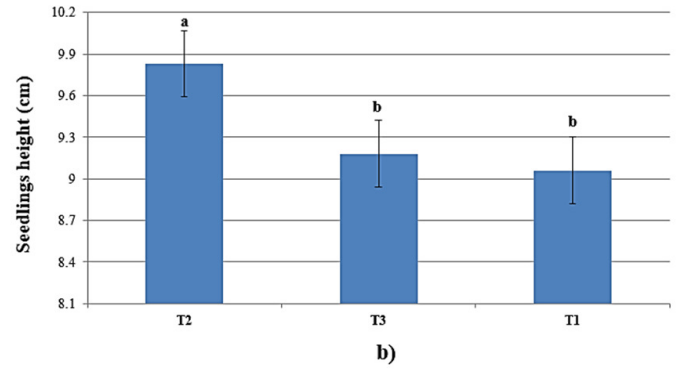

b)

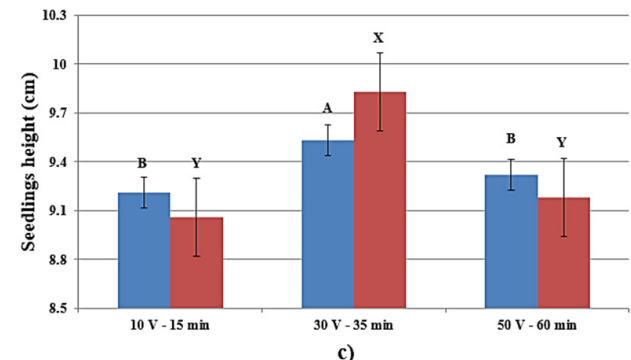

c)

Figure 6. The effects of electric field intensity (a) and timing intervals (b) as well as the interaction between these factors (c) on height of sessile oak seedlings

The bars represent the average \pm SE $(n=30)$. For each factor, different letters from top of bars indicate significant differences between treatments, according Tukey's test $(\alpha=0.05)$. I3 $=50 \mathrm{~V}, \mathrm{I} 2=30 \mathrm{~V}, \mathrm{I} 1=10 \mathrm{~V} ; \mathrm{T} 1=15 \mathrm{~min}, \mathrm{~T} 2=$ $35 \mathrm{~min}, \mathrm{~T} 3=60 \mathrm{~min}$.

\section{Seed germination and plantlets growth after $\gamma$ rays treatments}

Gamma rays treatments have a positive impact of seeds germination. Qi et al. (2015) investigated the impact of treatments with $\gamma$ rays on seeds of Arabidopsis thaliana and noted that seeds irradiation with lower dosages of $100 \mathrm{~Gy}$ stimulated the germination index. Maity et al. (2005) described the effects induced by $\gamma$ rays (50-350 Gy) on seeds of Oryza sativa and Phaseolus mungo. While irradiation at small dosages improved morphological features, exposure at higher dosages had a negative impact on the same parameters. Araújo et al. (2016) noted that stimulating effects of $\gamma$ rays were observed at small dosages (2-30 Gy), while large dosages (70 Gy) proved to be harmful to plants. Gamma rays proved to be, also, an efficient approach to improve seeds germination performance and seedlings stability for forestry species.

In this study a dosage of $2 \mathrm{~Gy}$ induced the highest value of the following germination indexes: (GP (\%) $=86.67 ; \mathrm{GI}=2.02 ; \mathrm{SE}=7.7$; and $\mathrm{CRG}=7.24)$, and at $6 \mathrm{~Gy}$ there was observed a decrease of values of the same parameters (Table 1). The similar behaviour was reported by Iglesias-Andreu et al. (2012) in Abies religiosa, the germination percentage grew with the growing frequency of mutation until 10 Gy and then lowered gradually with growth of $\gamma$ rays dosage. Habba (1992) for seeds of Hyoscyamus muticus observed that the germination percentage grew gradually until $100 \mathrm{~Gy}$. Marcu et al. (2013) and Bodele (2013) reported, also, the growth of germination parameters in small dosages of $\gamma$ rays.

Table 1. The $\gamma$ ray treatments of sessile oak seeds (Quercus petraea)

\begin{tabular}{|c|c|c|c|c|c|c|}
\hline \multirow{2}{*}{ Germination parameter } & \multirow{2}{*}{ Symbol } & \multirow{2}{*}{ Control } & \multicolumn{4}{|c|}{ Irradiation dosage } \\
\cline { 4 - 8 } & & & $\mathbf{G y}$ & $\mathbf{1 . 5} \mathrm{Gy}$ & $\mathbf{2 ~ G y}$ & $\mathbf{6 ~ G y}$ \\
\hline Germination percentage & GP $(\%)$ & 76.67 & 56.67 & 73.33 & 86.67 & 63.33 \\
\hline Germination index & GI & 1.42 & 1.02 & 1.30 & 2.02 & 1.06 \\
\hline Speed of emergence & SE & 4.3 & 5.9 & 4.5 & 7.7 & 5.3 \\
\hline Coefficient of germination speed & CRG & 5.79 & 5.52 & 5.71 & 7.24 & 5.43 \\
\hline
\end{tabular}


Our results showed that a dosage of irradiation of 2 Gy improved the growth parameters (plantlets diameter and height) in comparison with untreated plants (Figure 7).
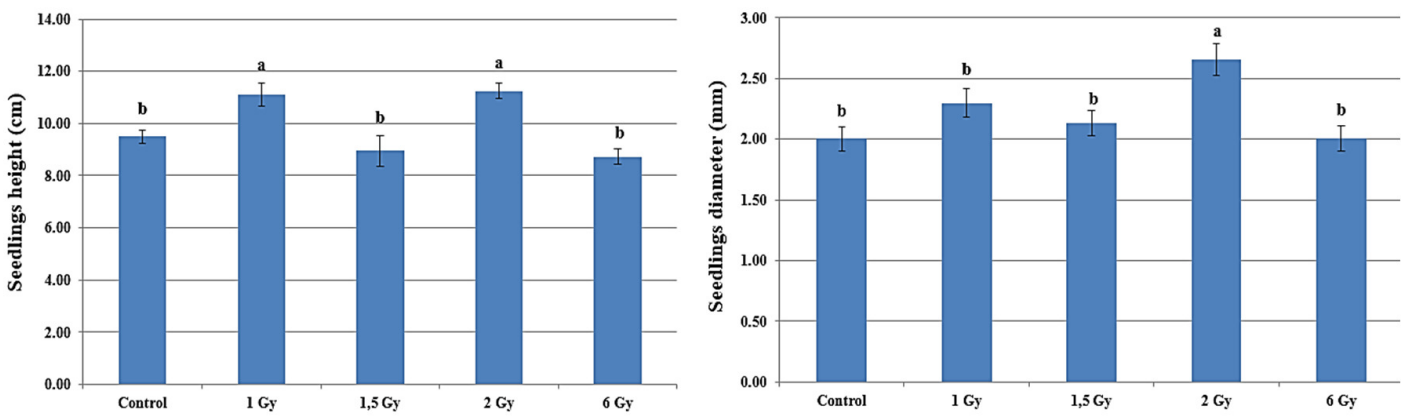

Figure 7. The effect of gamma rays treatments on diameter and height of sessile oak seedlings The bars represent the average $\pm S E(n=30)$. For each character, different letters from top of bars indicate significant differences between treatments, according to Tukey's test $(\alpha=0.05)$.

At the maximum dosage considered in this study (6 Gy) there was noted a decrease of growth parameters (diameter and height of plantlets) in comparison with control and more with those subjected to some smaller irradiation dosages (Figure 7). Similar to previous study and with the present study, $\gamma$ rays applied in small dosages (until 5 Gy) grew the germination percentage in comparison with non-irradiated or irradiated samples with larger dosages (Minisi et al., 2013). Gamma rays with smaller dosage stimulated, also, seeds' germination, vigour and seedlings growth at savage oat (Maherchandani, 1975), garden cherry (Majeed et al., 2010), nightshade (Abdel-Hady et al., 2008), okra (Dubey et al., 2007) and arugula (Moussa, 2006).

\section{Seed germination and plantlets growth after exposing seeds in EMF}

It was assessed that an EMF applied to latent seeds grows the development rate of barley, corn, beans, wheat and of some species of trees (Maffei, 2014). Moreover, an EMF with reduced frequency (16 Hz) can be used as method of improving seeds of sensitive species that germinate at low temperatures (Rochalska and Orzeszko-Rywka, 2005).

The germination study showed that sessile oak seeds subjected to EMF for 20 minutes induced the highest value of germination indexes (GP $=90.00 \%$ and $\mathrm{GI}=1.81$ ) while for SE no higher values were registered. The seeds subjected to EMF for 30 minutes registered the highest value for $\mathrm{CRG}=7.07$ (Table 2).

Table 2. The effect of electromagnetic field on seeds' germination of sessile oak (Quercus petraea)

\begin{tabular}{|c|c|c|c|c|c|}
\hline $\begin{array}{c}\text { Germination } \\
\text { parameter }\end{array}$ & Symbol & Control & 10 min & 20 min & 30 min \\
\hline Germination percentage & GP (\%) & 63.33 & 73.33 & 90.00 & 70.00 \\
\hline Germination index & GI & 1.09 & 1.28 & 1.81 & 1.61 \\
\hline Speed of emergence & SE & 10.5 & 4.5 & 3.7 & 9.5 \\
\hline $\begin{array}{c}\text { Coefficient of germination } \\
\text { speed }\end{array}$ & CRG & 5.92 & 6.15 & 6.24 & 7.07 \\
\hline
\end{tabular}

Our results showed that seeds exposed in EMF for 20 minutes produced plantlets with high diameter and with significant differences towards non-treated plants. In addition, an exposure of seeds in EMF for 20 minutes, or 30 minutes registered significantly superior differences for plantlets height (Figure 8). 

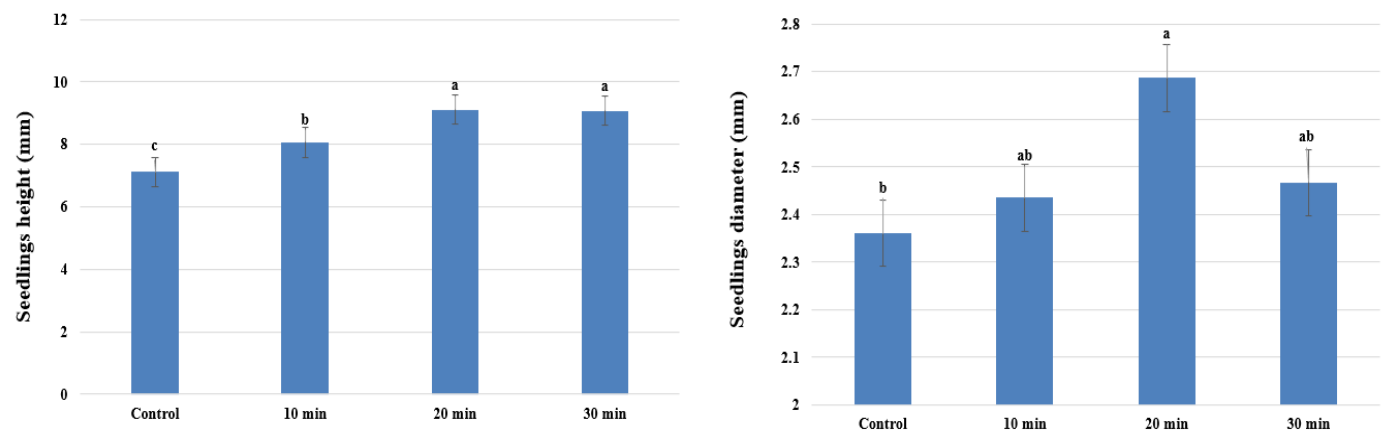

Figure 8. The seedlings diameter (a) and seedlings height (b) under electromagnetic field $\mathrm{B}=0,4 \mathrm{mT}$ and $\mathrm{i}=0,680 \mathrm{~A}$

The bars represent the average \pm SE $(n=30)$. For each of the character, different letters from top of bars indicate significant differences between treatments, according to Tukey's test $(\alpha=0.05)$.

Application of EMF promoted also the germination of beans seeds (Sakhnini, 2007). For beans seeds that were exposed to EMF of 87 until $226 \mathrm{mT}$ intensity, for 100 minutes, Sakhnini (2007) assessed a linear growth of germinative traits with the growing intensity of EMF. Mahajan and Pandey (2014) noted that an applied EMF improved germination of beans seeds even out of season

Iqbal et al. (2012) followed a study with pea seeds exposed to three different values of EMF and three different time intervals before sowing. The results of Iqbal et al. (2012) study showed an increase of vigour index with 86 , respectively, $205 \%$, and underlined that the treatment could be used in practice for accelerating germination.

At chickpea the application of EMF with a resistance from 0 to $250 \mathrm{mT}$ improved significantly the germination speed, length of seedlings and dried weight of seedlings. It was assessed that chickpea seeds treated electromagnetically can have better results under pluvial conditions (non-irrigated) in which a restrictive regime of soil humidity existed (Vashisth and Nagarajan, 2008).

\section{Conclusions}

The current results suggest that treatments of seeds with non-chemical factors might improve the seed germination and the seedlings features. The physical methods might be an alternative approach towards the chemical substances used nowadays and offers also ecological advantages as well as the possibility to be used at a scale with high efficiency.

\section{Authors' Contributions}

RH, OV and AMT designed the manuscript, wrote and authored most of the manuscript; IMM, SS, CS, HDV and PT collected the data; RH, IMM, HC, LH and AMT contributed data or analysis tools; RH, $\mathrm{OV}$ and AMT performed the analysis; HDV, HC and LH reviewed drafts of the paper and corrected the manuscript. All authors read and approved the final manuscript. 


\section{Acknowledgements}

We are indebted to the anonymous reviewers for their comments and suggestions. This research received no specific grant from any funding agency in the public, commercial, or not-for-profit sectors.

\section{Conflict of Interests}

The authors declare that there are no conflicts of interest related to this article.

\section{References}

Aas G (2000). Enzyklopädie der Holzgewächse: Handbuch und Atlas der Dendrologie. In: Roloff A, Weisgerber H, Lang UM, Stimm B, Schütt P (Eds). Vol. 3. Wiley-Vch Verlag, Weinheim.

Abdel-Hady MS, Okasha EM, Soliman SSA, Talaat M (2008). Effect of gamma radiation and gibberellic acid on germination and alkaloid production in Atropa belladonna L. Australian Journal of Basic and Applied Sciences 2:401-405.

Alan M (1974). Field Guide to the Trees of Britain and Northern Europe (Collins Field Guide). Harper Collins Distribution Services, New York.

Aldrich PR, Cavender-Bares J (2011). Genomics and breeding of oaks and their slightly less-domesticated wild oak relatives. In: Kole C (Ed). Wealth of Wild Species: Genetic, Genomic and Breeding Resources. New York, Springer-Verlag pp 89-130.

Alexander MP, Doijode SD (1995). Electromagnetic field, a novel tool to increase germination and seedling vigour of conserved onion (Allium cepa L.) and rice (Oryza sativa L.) seed with low viability. Plant Genet. Resources Newsletter 104:1-5.

AOSA I (1983). Seed vigor testing handbook. Contribution No.32 to handbook on seed testing. Association of Official Seed Analysis.

Araújo SDS, Paparella S, Dondi D, Bentivoglio A, Carbonera D, Balestrazzi A (2016). Physical methods for seed invigoration: advantages and challenges in seed technology. Frontiers in Plant Science 7:646. https://doi.org/10.3389/fpls.2016.00646

Ashraf M (2009). Biotechnological approach of improving plant salt tolerance using antioxidants as markers. Biotechnology Advances 27:84-93. https://doi.org/10.1016/j.biotechadv.2008.09.003

Belyavskaya NA (2004). Biological effects due to weak magnetic field on plants. Advances in Space Research 34(7):15661574. https://doi.org/10.1016/j.ast.2004.01.021

Bewley JD, Black M (1985). Dormancy and the control of germination. In: Seeds. Springer, Boston, MA. https://doiorg/10.1007/978-1-4615-1747-4_5

Bodele SK (2013). Effect of gamma radiation on morphological and growth parameters of Andrographis paniculata (Burm. F) Wall. Ex. Nees. Indian Journal of Applied Research 3(6):55-57. https://doi.org/10.20886/ijfr.2016.3.2.95-106

Bonner FT (1996). Responses to drying of recalcitrant seeds of Quercus nigra L. Annals of Botany 78:181-187. https://doi.org/10.1006/anbo.1996.0111

Chiapusio G., Sánchez AM, Reigosa MJ, González L, Pellissier F (1997). Do germination indices adequately reflect allelochemical effects on the germination process? Journal of Chemical Ecology 23:2445-2453. https://doi.org/10.1023/B:JOEC.0000006658.27633.15

Connor KF, Bonner FT (2001). The effects of desiccation on seeds of Acer saccharinum and Aesculus pavia: recalcitrance in temperate tree seeds. Trees 15:131-136. https://doi.org/I 0.10071s004680100092

Connor KF, Sowa $S$ (2002). Recalcitrant behaviour of temperate forest tree seeds: storage, biochemistry, and physiology. In: Outcalt KW (Ed). Proceedings of the Eleventh Biennial Southern Silvicultural Research Conference. USDA Forest Service, General Technical Report SRS-48, Denver, CO.

Connor KF, Sowa S (2003). Effects of desiccation on the physiology and biochemistry of Quercus alba acorns. Tree Physiology 23(16):1147-1152. https://doi.org/10.1093/treephys/23.16.1147 
De Micco V, Arena C, Pignalosa D, Durante M (2011). Effects of sparsely and densely ionizing radiation on plants. Radiation and Environmental Biophysics 50(1):1-19. https://doi.org/10. 1007/s00411-010-0343-8

De Souza A, Garcia D, Sueiro L, Gilart F, Porras E, Licea L (2006). Pre-sowing magnetic treatments of tomato seeds increase the growth and yield of plants. Journal of the Bioelectromagnetics Society, The Society for Physical Regulation in Biology and Medicine, The European Bioelectromagnetics Association 27(4):247-257. https://doi.org/10.1002/bem.20206

Doody ND, O'Reilly C (2008). Drying and soaking pre-treatments affect germination in pedunculate oak. Annals of Forest Science 65:509. https://doi.org/10.1051/forest:2008027

Dubey AK, Yadav JR, Singh B (2007). Studies on induced mutations by gamma irradiation in okra (Abelmoschus esculentus (L.) Monch.). Progressive Agriculture 7:46-48.

Eaton E, Caudullo G, Oliveira S, de Rigo D (2016). Quercus robur and Quercus petraea in Europe: distribution, habitat, usage and threats. In: San-Miguel-Ayanz J, de Rigo D, Caudullo G, Houston D, Urrant T, Mauri A (Eds). European Atlas of Forest Trees Species 160-163.

Es'kov EK, Rodionov YA (2010). Initial growth processes in seeds in magnetic fields, strengthened or weakened in relation to the geomagnetic field. Biology Bulletin 37(1):49-55. https://doi.org/10.1134/S1062359010010073

Esnault MA, Legue F, Chenal C (2010). Ionizing radiation: advances in plant response. Environmental and Experimental Botany 68(3):231-237. https://doi.org/10.1016/j.envexpbot.2010.01.007

Fetouh MI, Hassan FA (2014). Seed germination criteria and seedling characteristics of Magnolia grandiflora L. trees after cold stratification treatments. International Journal of Current Microbiology and Applied Sciences 3(3):235241.

Giertych MJ, Suszka J (2011). Consequences of cutting off distal ends of cotyledons of Quercus robur acorns before sowing. Annals of Forest Science 68:433-442. https://doi.org/10.1007/s13595-011-0038-6

Gordon AG (1992b). Seed storage. In: Seed Manual for Forest Trees. HMSO, Forestry Commission, London pp 98-104.

Gosling P (1989). The effect of drying Quercus robur acorns to different moisture contents, followed by storage, either with or without imbibition. Forestry 62:41-50. https://doi.org/10.1093/forestry/62.1.41

Grewal HS, Maheshwari BL (2011). Magnetic treatment of irrigation water and snow pea and chickpea seeds enhances early growth and nutrient contents of seedlings. Bioelectromagnetics 32(1):58-65. https://doi.org/10.1002/bem.20615

Grüner M, Horvatić M, Kujundžić D, Magdalenić B (1992). Effect of gamma irradiation on lipid components of soya protein products. Nahrung-Food 36:443-450.

Habba IE (1992). Physiological effect of gamma rays on growth and productivity of Hyoscyamus muticus L. and Atropa belladonna L (PhD Thesis) Cairo University.

Huang HH, Wang SR (2008). The effects of inverter magnetic fields on early seed germination of mung beans. Bioelectromagnetics 29(8):649-657. https://doi.org/10.1002/bem.20432

Iglesias-Andreu LG, Octavio-Aguilar P, Bello-Bello J (2012). Current importance and potential use of low doses of gamma radiation in forest species. Gamma Radiation 265-280. https://doi.org/10.5772/36950

Ikram N, Dawar S, Abbas Z, Javed Z (2010). Effect of (60 cobalt) gamma rays on growth and root rot diseases in mungbean (Vigna radiata L.). Pakistan Journal of Botany 42(3):2165-2170.

Iqbal M, Muhammad D, Hag ZU, Jamil Y, Ahmad M (2012). Effect of pre-sowing magnetic field treatment to garden pea (Pisum sativum L.) seed on germination and seedling growth. Pakistan Journal of Botany 44:1851-1856.

Islam AK, Anuar N, Yaakob Z (2003). Effect of genotypes and pres-sowing treatments on seed germination behavior of Jatropha. Asian Journal of Plant Science 8(6):433-439. https://doi.org/10.3923/ajps.2009.433.439

Kheloufi A, Mansouri L, Aziz N, Sahnoune M, Boukemiche S, Ababsa B (2018). Breaking seed coat dormancy of six tree species. Reforesta (5):4-14. https://doi.org/10.21750/REFOR.5.02.48

Kiong A, Ling Pick A,Grace Lai SH, Harun AR (2008). Physiological responses of Orthosiphon stamineus plantlets to gamma irradiation. American-Eurasian Journal of Sustainable Agriculture 2(2):135-149.

Lynikeine S, Pozeliene A, Rutkauskas G (2006). Influence of corona discharge field on seed viability and dynamics of germination. International Agrophysics 20(3):195-200.

Maffei ME (2014). Magnetic field effects on plant growth, development, and evolution. Frontiers in Plant Science 5:445. https://doi.org/10.3389/fpls.2014.00445

Mahajan TS, Pandey OP (2014). Magnetic-time model at off-season germination. International Agrophysics 28:57-62. https://doi.org/10.2478/intag-2013-0027 
Maherchandani N (1975). Effects of gamma radiation on the dormant seed of Avena fatua L. Radiation Botany 15(4):439443. https://doi.org/10.1016/0033-7560(75)90018-6

Maity JP, Mishra D, Chakraborty A, Saha A, Santra SC, Chanda S (2005). Modulation of some quantitative and qualitative characteristics in rice (Oryza sativa L.) and mung (Phaseolus mungo L.) by ionizing radiation. Radiation Physics and Chemistry 74:391-394. https://doi.org/10.1016/j.radphyschem.2004.08.005

Majeed A, Ahmad H, Muhammad Z (2010). Variation in chlorophyll contents and grain yield of Lepidium sativum L. as induced by gamma irradiation. International Journal of Biological Sciences and Engineering 1(2):147-151.

Manos PS, Doyle JJ, Nixon KC (1999). Phylogeny, biogeography and processes of molecular differentiation in Quercus subgenus Quercus (Fagaceae). Molecular Phylogenetics and Evolution 12(3):333-349. https://doi.org/10.1006/mpev.1999.0614

Marcu D, Damian G, Cosma C, Cristea V (2013). Gamma radiation effects on seed germination, growth and pigment content, and ESR study of induced free radicals in maize (Zea mays). Journal of Biological Physics 39:625-634. https://doi.org/10.1007/s10867-013-9322-Z

Mijnsbrugge KV, Turcsán A, Maes J, Duchêne N, Meeus S, Steppe K, Steenackers M (2016). Repeated summer drought and re-watering during the first growing year of oak (Quercus petraea) delay autumn senescence and bud burst in the following spring. Frontiers in Plant Science 7:419. https://doi.org/10.3389/fpls.2016.00419

Minisi FA, El-Mahrouk ME, Rida MEDF, Nasr MN (2013). Effects of gamma radiation on germination, growth characteristics and morphological variations of Moluccella laevis L. American-Eurasian Journal of Agricultural and Environmental Sciences 13:696-704. https://doi.org/10.5829/idosiaejaes.2013.13.05.1956

Molamofrad F, Lotfia M, Khazaeib J, Tavakkol-Afsharic R, Shaiegani-Akmald AA (2013). The effect of electric field on seed germination and growth parameters of onion seeds (Allium cepa). Advanced Crop Science 3(4):291-298.

Moussa HR (2006). Role of gamma irradiation in regulation of $\mathrm{NO}_{3}$ level in rocket (Eruca vesicaria subsp. sativa) plants. Russian Journal of Plant Physiology 53:193-197. https://doi.org/10.1134/S1021443706020075

Muller C (1990). Problemes poses par la conservation des glands. Revue Forestière Française 42:212-214. https://doi.org/10.4267/2042/26064

Mustafayev SA (1974). Using of high voltage electrical current on obtaining early maturing cotton cultivars. In: Proceeding of the Conference of USSR on Science and Social Sciences, Baku-Azerbaijan pp 150-153.

Nicolescu VN (2010). Ecology and silviculture of sessile oak (Quercus petraea (Matt.) Liebl.) in Romania. Spanish Journal of Rural Development 1(2):35-51.

Oldfield S, Eastwood A (2007). The red list of oaks. Cambridge, UK: Fauna and Flora International.

Özbingol N, O’Reilly C (2005). Increasing acorn moisture content followed by freezing storage enhances germination in pedunculate oak. Forestry 78(1):73-81. https://doi.org/10.1093/forestry/cpi007

Pedrol N, Puig CG, López-Nogueira A, Pardo-Muras M, González L, Souza-Alonso P (2018). Optimal and synchronized germination of Robinia pseudoacacia, Acacia dealbata and other woody Fabaceae using a handheld rotary tool: concomitant reduction of physical and physiological seed dormancy. Journal of Forestry Research 29(2):283290. https://doi.org/10.1007/s11676-017-0445-0

Piri I, Babayan M, Tavassoli A, Javaheri M (2011). The use of gamma irradiation in agriculture. African Journal of Microbiology Research 5(32):5806-5811.

Poulsen KM, Eriksen EN (1992). Physiological aspects of recalcitrance in embryonic axes of Quercus robur L. Seed Science Research 2:215-221. https://doi.org/10.1017/S0960258500001409

Pukacka S, Malec M, Ratajczak E (2011). ROS production and antioxidative system activity in embryonic axes of Quercus robur seeds under different desiccation rate conditions. Acta Physiologiae Plantarum 33:2219-2227. https://doi.org/10.1007/s11738-011-0761-5

Qi W, Zhang L, Wang L, Xu H, Jin Q, Jiao Z (2015). Pre-treatment with low-dose gamma irradiation enhances tolerance to the stress of cadmium and lead in Arabidopsis thaliana seedlings. Ecotoxicology and Environmental Safety 115:243-249. https://doi.org/10.1016/j.ecoenv.2015.02.026

Reyes O, Casal M (2006). Seed germination of Quercus robur, Q. pyrenaica and Q. ilex and the effects of smoke, heat, ash and charcoal. Annals of Forest Science 63:205-212. https://doi.org/10.1051/forest:2005112

Rochalska M, Orzeszko-Rywka A (2005). Magnetic field treatment improves seed performance. Seed Science and Technology 33:669-674. https://doi.org/10.15258/sst.2005.33.3.14

Rotcharoen T, Khan-Ngern W, Nitta S (2002). The effect of electric field to rice plant growing. ICEMC, Bangkok.

Rushforth K (1999). Trees of Britain and Europe. Harper Collins, London. 
Sakhnini L (2007). Influence of $\mathrm{Ca}^{2+}$ in biological stimulating effects of AC magnetic fields on germination of bean seeds. Journal of Magnetism and Magnetic Materials 310:1032-1034. https://doi.org/10.1016/j.jmmm.2006.11.077

Sjödin J (1962). Some observations in X1 and X2 of Vicia faba L., after treatment with different mutagens. Hereditas 48:565-586.

Smigel VN, Kovalenko AF, Babitsin GS (1968). Shocking of potato before planting with high voltage electrical current. Journal of Mechanization and Electrification Research Institute of Celyabinsk 31:76-82.

Suszka B, Muller C, Bonnet-Masimbert M (1996). Seeds of forest broadleaves: from harvest to sowing. INRA, Paris.

Suszka B, Tylkowski T (1980). Storage of acorns of the English oak (Quercus robur L.) over 1-5 winters. Arboretum Kornickie 25:199-229.

Vashisth A, Nagarajan S (2010). Effect on germination and early growth characteristics in sunflower (Helianthus annuus) seeds exposed to static magnetic field. Journal of Plant Physiology 167:149-156. https://doi.org/10.1016/j.jplph.2009.08.011

Vasilevski G (2003). Perspectives of the application of biophysical methods in sustainable agriculture. Bulgarian Journal of Plant Physiology 29(3):179-186.

Wi SG, Chung BY, Kim JS, Kim JH, Baek MH, Lee JW, Kim YS (2006). Effects of gamma irradiation on morphological changes and biological responses in plants. Micron 38(1):553-564. https://doi.org/10.1016/j.micron.2006.11.002

Wiendl FM, Wiendl FW, Wiendl JA, Vedovatto A, Arthur V (1995). Increase of onion yield through low dose of gamma irradiation of its seeds. Radiation Physics and Chemistry 46:793-795. https://doi.org/10.1016/0969 $806 X(95) 00263-W$

World Organisation of Health and Nutrition in Agriculture (1988). Organisation of United Nations.

Xia K, Daws MI, Hay FR, Chen WY, Zhou ZK, Pritchard HW (2012). A comparative study of desiccation responses of seeds of Asian evergreen oaks, Quercus subgenus Cyclobalanopsis and Quercus subgenus Quercus. South African Journal of Botany 78:47-54. https://doi.org/10.1016/j.sajb.2011.05.001
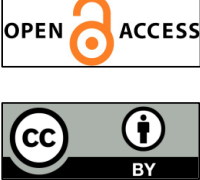

The journal offers free, immediate, and unrestricted access to peer-reviewed research and scholarly work. Users are allowed to read, download, copy, distribute, print, search, or link to the full texts of the articles, or use them for any other lawful purpose, without asking prior permission from the publisher or the author.

License - Articles published in Notulae Botanicae Horti Agrobotanici Cluj-Napoca are Open-Access, distributed under the terms and conditions of the Creative Commons Attribution (CC BY 4.0) License.

(c) Articles by the authors; UASVM, Cluj-Napoca, Romania. The journal allows the author(s) to hold the copyright/to retain publishing rights without restriction. 